\title{
UNIWERSYTET W CZASACH BEZMYŚLNOŚCI
}

\section{UNIVERSITY IN TIMES OF THOUGHTLESSNESS}

\section{SUMMARY}

In the article I put forward the thesis that the enormous development of science and new technologies, not only did not stop the thoughtlessness, but even deepened it. One can have the impression that we are experiencing some extraordinary intensification of irrationalism, lack of critical thinking, naivety, and questioning of scientific authorities. This situation presents us with three issues that I will try to answer: 1 . What is thinking and how do we think? 2. What are the modern causes of thoughtlessness? 3 . What should be the role of universities in times of thoughtlessness?

KEYWORDS: thoughtlessness, critical thinking, scientific authorities, university

Jeden z najwybitniejszych myślicieli XX wieku Martin Heidegger rozpoczął swoją książkę Was heisst Denken od zdania: „Dawno nie zastanawialiśmy się nad istotą myślenia”. Jego uczennica i przyjaciółka Hannah Arendt, przyglądając się procesowi Eichmanna w Jerozolimie, stwierdziła, że zło jest bezmyślne. Znaleźli się po dwóch różnych stronach. On jako członek NSDAP miał nadzieję, że wykorzysta władzę Adolfa Hitlera do reformy niemieckich uniwersytetów. Nie był jednak tylko pragmatykiem. Schwartze Hefte, jego prywatne notatki, a także list skierowany do brata z okazji Bożego Narodzenia, kiedy to jako prezent świąteczny ofiarował mu Mein Kampf, dowodzą bardziej intymnych związków Heideggera z nazizmem. Ona wyemigrowała do Stanów Zjednoczonych i opublikowała tam m.in. dwa tomy: jeden o myśleniu, drugi 
o woli. Już te dwie historie bliskich sobie wybitnych postaci dowodzą, że kierunek ich myślenia związany był ściśle z ich życiowymi decyzjami.

W niniejszym tekście postaram się odpowiedzieć na trzy pytania. Po pierwsze, czym jest myślenie? Po drugie, dlaczego, jak sądzę, żyjemy w czasach bezmyślności? Po trzecie, jaka jest rola uniwersytetów w tych czasach?

1. Czym jest myślenie? Patrząc na człowieka z perspektywy natury, musimy stwierdzić, że jest on zwierzęciem wybrakowanym, nieprzystosowanym, posiadającym rozmaite naturalne deficyty - stwierdził królewiecki filozof Immanuel Kant. Człowiek nie ma ani siła lwa, ani kłów tygrysa, ani pazurów orła, by przetrwać. Potrzebuje o wiele dłuższego niż inne zwierzęta okresu adaptacji. Z perspektywy natury człowiek jest zatem istotą dziwną. Natura przeznaczyła mu jednak odmienną drogę rozwoju. Nie dając mu naturalnego instynktu, zmusiła go do rozwoju intelektualnego potencjału. To właśnie dzięki niemu człowiek może przezwyciężyć swe naturalne deficyty. Nie tylko zrekompensowaliśmy te deficyty, ale wytworzyliśmy urządzenia, dzięki którym poruszamy się szybciej od najszybszych zwierząt, potrafimy latać, pomimo braku naturalnych po temu zdolności. Wręcz zapanowaliśmy nad procesami natury, próbujemy panować nad procesami społecznymi, a także nad własnym życiem.

Ten sposób kompensaty jest jednak dwuznaczny. Jest, jak pokazali to Max Horkheimer i Theodor Wissengrund Adorno w Dialektyce oświecenia, źródłem władzy. Najcelniej ten związek między władzą i wiedzą wyraził Francis Bacon: „Tyle możemy, ile wiemy”. Wiedza jest nie tylko źródłem otwierającego się pola możliwości, ale także źródłem panowania. Kto w renesansie posiadł umiejętność żeglowania, posługiwania się kompasem i prochem strzelniczym, przed tym otwarła się nie tylko perspektywa odkryć nowych lądów, ale także, w następstwie, ich podboju, niszczenia rodzimych kultur, mordowania tubylców. Uruchomiliśmy niewyobrażalne i jeszcze nieprzewidywalne źródła mocy. W XX wieku zbudowaliśmy obozy koncentracyjne i łagry. Z perspektywy renesansowego humanizmu nie mamy już podstaw mówić, że „człowiek to brzmi dumnie". Owszem, stworzyliśmy dzieła, które dają nam podstawę bycia, jak pisał Blaise Pascal, czynią z nas „chlubę wszechświata”. Jednocześnie jednak, jak w tej samej sentencji stwierdził myśliciel, jesteśmy ,jego zakałą”. Sześćdziesiąt lat temu Otto Friedrich Bollnow w artykule Rozum a siły irracjonalne stwierdził: 
Sytuację dzisiejszego człowieka w zgodnym przekonaniu różnych obserwatorów znamionuje świadomość całkowitego braku osłony pośród wrogo napierającego świata. Człowiek stał się w daleko idącym sensie bezdomny i czuje, mówiąc za Rilkem, że „nie jest bezpiecznie zadomowiony w świecie, który chce zrozumieć1.

Z czego wynika ta dwuznaczność myślenia? Mylimy się, gdy sprowadzamy myślenie do czynności intelektu. Intelekt ma charakter narzędziowy. Jest sztuką pojęciowego konstruowania i nadbudowanego nad nim technicznego opanowania zadań postawionych człowiekowi przez życie. Dzięki intelektowi biernemu możemy rozumieć twierdzenia matematyczne, dokonać obliczeń, wyprowadzić wnioski, ale także znając strukturę jakiegoś języka, rozumieć tych, którzy nim mówią. Dzięki intelektowi czynnemu nabywamy takich umiejętności, jak obsługa programów komputerowych czy tworzenie nowych materiałów. Nie ulega wątpliwości, że dzięki zdolnościom intelektualnym rozwinęliśmy naukę i dokonaliśmy niewyobrażalnego dotąd postępu technicznego.

Intelekt stanowi jednak tylko niewielki fragment naszych procesów myślowych. Niezmiernie ważną rolę odgrywają w naszym myśleniu przekonania, nazywane także czasami wiarą. Każdy z nas w coś wierzy, nie ma zatem niewierzących. Różnimy się jedynie przedmiotem tej wiary. Jedni wierzą w istnienie Boga, inni w Jego nieistnienie. Jedni w materię, inni w ducha, jedni w zamach smoleński, inni w płaską Ziemię. Przekonania, jak stwierdził José Ortega y Gasset, nie są ideami, które mamy, lecz którymi jesteśmy. To nie o nich myślimy, lecz myślimy w nich. Są bowiem dla nas niepodważalne. Czasami zdarza się, że je zmieniamy, ale dokonuje się to nie poprzez intelektualny dyskurs, lecz na drodze życiowych doświadczeń. Myślimy bowiem z głębi naszego życia. Nasze przekonania kształtują się w sposób dość tajemniczy. Możemy wyodrębnić w nich jedynie pewne wątki. Po pierwsze, na nasze myślenie ma wpływ historyczna epoka, w jakiej żyjemy. Następnie kultura i język. Dalej są to uwarunkowania indywidualne związane z rodzinną tradycją, jej światopoglądem. Następnie zdarzenia losowe. Na żadne $\mathrm{z}$ tych uwarunkowań nie mamy wpływu. Nie decydujemy ani o czasie naszego życia, kulturze, języku, rodzinie, zdarzeniach losu. Mamy wpływ jedynie na naszą wolność. Myślenie oparte na przekonaniach dlatego jest wiarą, że nie ma tu rozstrzygających racjonalnych argumentów, a jeśli są, to je odrzucamy. Uznajemy bowiem coś za prawdzi-

${ }^{1}$ O.F. Bollnow, Rozum a sity irracjnalne, tłum. E. Paczkowska-Łagowska, „Znak” 11 (1979), s. 1188. 
we lub odrzucamy jako fałszywe, gdyż jest zgodne bądź niezgodne z naszymi przekonaniami. Nawet intelekt jest przedmiotem wiary. Niejednokrotnie nas on zwiódł i zawiódł tak, że powinniśmy go porzucić, jednak wciąż w niego wierzymy.

Istotny wpływ na nasze przekonania mają mitologia i religia, które możemy wyodrębnić jako podzbiór w obszarze naszych przekonań. Przekonania są nam konieczne jako podpory życia. Dają nam odpowiedzi na pytania, na które nie jest zdolny dać intelekt.

Nie wiemy, jak kształtują się nasze przekonania, które radykalnie nas różnią. Z pewnością mają na to wpływ wrażliwość, rodzina, lektury, nauczyciele. Możemy jedynie wyodrębnić przekonania otwierające i zamykające. Pierwsze rozwijają nasze myślenie, drugie je zasadniczo ograniczają i zamykają. Przekonania zamknięte budzą emocje i uruchamiają rozmaite mitologie.

Kolejną władzą myślenia jest rozum, który za O.F. Bollnowem chciałbym wyodrębnić od intelektu. Intelekt ma jedynie charakter narzędziowy. Nie jest on ani dobry, ani zły, podobnie jak narzędzia, którymi się on posługuje. Internet jako narzędzie może służyć do komunikacji, ale także „hejtu” i cyberprzestępczości. Umiejętność wymiany genu nie jest moralnie ani zła, ani dobra. Czy jednak wykorzystamy ją do leczenia wad genetycznych, czy eugeniki, nie zależy od intelektu. Stwierdził kiedyś Blaise Pascal: „Silmy się tedy dobrze myśleć: oto zasada moralna”2. Dobrze to nie znaczy tylko prawidłowo, bezbłędnie, zgodnie z zasadami. Tak myśli intelekt, ten bowiem jest ślepy na wartości i cele. Dlatego może łączyć się z przekonaniami irracjonalnymi, fanatycznymi i mitologią. Pisał Bollnow:

Zimny i wyrachowany intelekt może wstąpić na służbę przestępczej namiętności. (...) Intelekt już z góry kryje w sobie autentyczne niebezpieczeństwo, wydając w połączeniu z namiętnością krańcowy fanatyzm. Fanatyzm zdefiniować można wręcz jako zracjonalizowaną namiętność

Dlatego intelekt powinien być wspierany przez rozum. A rozum „myśli dobrze" nie wtedy, gdy myśli prawidłowo, lecz gdy kieruje się dobrem. Jest to ta władza myślenia, która kształtuje się pod wpływem rozmowy i zdolna jest do rozumienia innych. Człowiekiem rozumnym nazywamy bowiem tego, kto

\footnotetext{
${ }^{2}$ B. Pascal, Myśli, tłum. T. Żeleński, Warszawa 1953, s. 113.

${ }^{3}$ O. F. Bollnow, Rozum a sity irracjonalne, dz. cyt., s. 1203.
} 
daje się wyprowadzić z opanowującego go afektu i emocji i staje się zdolny do rozumnej rozmowy:

Rozum oznacza tu więc medium wspólnoty, w której ludzie, nawzajem się sobie przysłuchując, mogą spotkać się w rozmowie. (...) Kto pozwala ze sobą mówić, ten jest człowiekiem, który nie upiera się tępo przy swoich zamiarach, który ze swej strony wychodzi naprzeciw drugiemu, i w obopólnych staraniach gotowy jest do twórczego kompromisu. (...) Usunąć napięcia i stworzyć możliwość bezkolizyjnego współżycia - oto dokonanie rozumu ${ }^{4}$.

Intelekt nauczy nas, jak zbudować dom. Ale to za mało. Jedynie rozum nauczy, jak w nim pokojowo współzamieszkiwać.

Jest jeszcze rozsądek. To władza podejmowania rozważnych decyzji między przeciwieństwami. Człowiek jest bowiem związkiem przeciwieństw. Jest jednocześnie istotą materialną i duchową, przyrodniczą i tworzącą kulturę, skończoną i pragnącą nieskończoności, wolną i odpowiedzialną, indywidualną i wspólnotową, sprawiedliwą i kochającą, aktywną i kontemplatywną, otwartą i zamkniętą, wychyloną ku przyszłości i zanurzoną w przeszłości. Brak równowagi między tymi przeciwieństwami prowadzi zawsze do negatywnych doświadczeń i groźnych kryzysów, zarówno społecznych, jak i osobistych. Sprawiedliwość bez miłości przemienia się w niesprawiedliwość, a miłość bez sprawiedliwości rodzi emocjonalną ślepotę. Wolność bez odpowiedzialności może przemienić się w anarchię, podobnie jak odpowiedzialności bez wolności w tyranię. Indywidualizm bez relacji społecznych może przekształcić się w egoizm społeczny, a relacje społeczne nieuwzględniające odrębności osób w kolektywizm. Kontemplacja pozbawiona działania może przemienić się w narcyzm, a działanie bez kontemplacji w czysty aktywizm.

Gdzie naznaczyć granicę między życiem zaangażowanym w materialność a otwarciem się na duchowość, gdzie ograniczyć miłość na rzecz sprawiedliwości lub sprawiedliwość na rzecz miłości, wolność na rzecz odpowiedzialności lub odpowiedzialność na rzecz wolności, relacje społeczne na rzecz samotności lub samotność na rzecz relacji? Na te pytania może każdorazowo odpowiedzieć nam jedynie rozsądek. Rozsądny jest ten, kto umie tę granice każdorazowo określić. A określić ją nie jest łatwo, gdyż za każdym razem leży ona gdzie indziej. Rozum i rozsądek to mądrość. Słowo obecnie rzadkie. Nie występuje w Krajowych Ramach Kwalifikacji. Już ta różnica między intelektem

${ }^{4}$ Tamże, s. 1203-1204. 
a rozumem pokazuje, że można jednocześnie być człowiekiem niezmiernie intelektualnie sprawnym i bezmyślnym. To dobre przejście do punktu drugiego.

2. Paradoks naszego położenia polega na tym, że olbrzymi rozwój technologii i nauki nie tylko nie wyhamował irracjonalizmu, ale wręcz go pogłębił. Doświadczamy obecnie jakiejś szczególnej intensyfikacji irracjonalizmu, bezmyślności, poglądów dalekich od rozumu i rozsądku. Chciałbym na chwilę zatrzymać się przy jednym z przejawów współczesnych czasów bezmyślności, czyli przeciętności. W wierszu Otchłań Ewa Lipska pisze z goryczą:

Siedzę pod byle jakim niebem

I słucham co mówi przeciętność 5 .

Przeciętność można zdefiniować jako uwięzienie w łatwej do powtarzania słownej „papce”, płynącej z radia, telewizji, przelewającej się w Internecie. Ksiądz Józef Tischner trafnie wyraził ją poprzez metaforę targowiska:

Targowiska mają swoją siłę przyciągania. Zniewalają nasze oczy, zmuszają do patrzenia na to, co jest wystawione. Zniewalają nasze uszy, zmuszają do słuchania tego, co jest wykrzyczane. Targowisko nie pozwala przekroczyć swej przestrzeni, wciąż zmusza do powrotu, do oglądania wiele razy tego samego. Przede wszystkim targowisko narzuca nam swój język. Kto przebywał czas jakiś na targowisku, nie umie mówić inaczej niż językiem targowiska. Nie potrafi również myśleć inaczej - staje się częścią targowiska ${ }^{6}$.

Współczesnym diagnostą bezmyślności jako przeciętności był wspomniany wyżej hiszpański myśliciel José Ortega y Gasset. Nazwał ją buntem mas. Stwierdził:

Być może mylę się, ale wydaje mi się, że obecnie pisarz, kiedy bierze do ręki pióro, by napisać coś na znany mu gruntownie temat, powinien pamiętać o tym, że przeciętny czytelnik, dotąd tym problemem niezainteresowany, nie będzie czytał dla poszerzenia własnej wiedzy, lecz odwrotnie - po to, by wydać na autora wyrok skazujący, jeśli treść jego dzieła nie będzie zbieżna $\mathrm{z}$ banalną przeciętnością umysłu owego czytelnika. Jeśli składające się na masę jednostki uważają się za szczególnie uzdolnione, to mamy wówczas do czynienia tylko z błędem jednostkowym, nie z socjologicznym przewrotem. Dla chwili obecnej

${ }^{5}$ E. Lipska, Otchłań, w: tejże, Gdzie Indziej, Kraków 2005, s. 29.

${ }^{6}$ J. Tischner, Wędrówki w krainę filozofów, Kraków 2008, s. 63. 
charakterystyczne jest to, że umysly przeciętne i banalne, wiedzac o swej przeciętności i banalności, maja czelność domagać się prawa do bycia przeciętnymi i banalnymi i do narzucania tych cech wszystkim innym. (...) To właśnie uznałem (...), za cechę charakterystyczną dla naszych czasów: nie to, że człowiek pospolity wierzy, iż jest jednostką nieprzeciętną, a nie pospolitą, lecz to, że żąda praw dla pospolitości, czy wręcz domaga się tego, by pospolitość stała się prawem

Współczesny nowy bunt mas, który ogarnia różne rejony Europy i świata, został jeszcze wzmocniony przez rozwój nowych technologii informacyjnych i medialnych. Współczesnym targowiskiem stał się Internet, który zamienił życie wielu ludzi w nieustający karnawał. Karnawał średniowieczny, przewracający do góry nogami istniejący porządek i poddający krytyce obowiązujące hierarchie norm i wartości, trwał kilka dni. Internetowy karnawał życia jest permanentny. Karnawał średniowieczny posługiwał się maską. Dzisiaj, pisze słoweńska pisarka Dubravka Ugrešić:

mali ludzie rzucili się, by pozostawić po sobie ślady, rozwijając przy tym w sobie niespotykany apetyt: jedni rozbierają się do naga i pokazują pupy, drudzy genitalia; jedni śpiewają, drudzy piszą; jedni tańczą, drudzy malują; niektórzy zaś, takie multipleksy w ludzkim wydaniu, robią wszystko naraz. Mały człowiek zdobył w końcu władzę medialną, wygłasza publiczne wykłady.

Paradoksalnie rozwój nowych technologii nie wspiera naszej odpowiedzialności, a wręcz z niej zwalnia. Postęp oznacza nie tylko akumulację, ale także polepszenie. Gdyby oznaczał tylko akumulację, to o zbieraczu śmieci, którego zasoby codziennie się zwiększają, musielibyśmy powiedzieć, że jest człowiekiem postępowym. W średniowieczu, gdy przepisywano księgi ręcznie całymi latami na kosztownym pergaminie, przepisywano jedynie arcydzieła. Od wynalezienia czcionki przez Gutenberga było już coraz gorzej. Kto pisał jeszcze na maszynie do pisania, czuł odpowiedzialność za słowo na swoich palcach. Wiedział, co się stanie, gdy źle sformułuje myśl. Dzisiaj, gdy piszemy na komputerach metodą „wytnij”, „wklej”, spadł radykalnie poziom naszego myślenia, a półki biblioteczne i Internet zalane są przeciętnością. Za odkrycie kopernikańskie zaczyna uchodzić wpis na Facebooku: „Dzisiaj o 7.00 wypiłam kawę”.

Nowe technologie nie tylko zwalniają nas z odpowiedzialności, ale także rozleniwiają. Współczesna cywilizacja techniczna, która jest cywilizacją ułatwień, przyczynia się także do intelektualnego lenistwa. W świecie tech-

\footnotetext{
${ }^{7}$ J. Ortega y Gasset, Bunt mas, s. 78-79.
} 
niki wszystko jest skuteczne. Wystarczy szybko poruszać prawym kciukiem. Naciskamy i działa. W sferze ducha nic tak nie działa. Przeczytanie książek, przemyślenie myśli, refleksja wymagają dużego wysiłku i nakładu pracy. Jeszcze w okresie międzywojennym 16-latkowie czytali w polskich liceach klasycznych Platona po grecku. Dzisiaj jest to niewyobrażalne nawet dla 20-latków.

$\mathrm{Na}$ dominację przeciętności wpływa wreszcie brak odwagi myślenia. Przeciętność sytuuje się bowiem pośrodku między tymi, którzy żyją ideologią lub z ideologii, a tymi, którzy mają odwagę krytycznie o niej myśleć. Pisał Immanuel Kant w artykule Sapere Aude:

Do wejścia na drogę Oświecenia nie potrzeba niczego prócz wolności (...), mianowicie wolności czynienia wszechstronnego, publicznego użytku ze swego rozumu. A jednak ze wszystkich stron słyszę pokrzykiwanie: nie myśleć! Oficer woła: nie myśleć! Ćwiczyć! Radca finansowy: nie myśleć! Płacić! Ksiądz: nie myśleć! Wierzyć! (...) Wszędzie więc mamy do czynienia z ograniczeniami wolności. Które jednak z nich są przeszkodą dla Oświecenia, a które nie i raczej nawet pomagają Oświeceniu - na to pytanie odpowiadam: publiczny użytek ze swego rozumu musi być zawsze wolny i tylko taki użytek może doprowadzić do urzeczywistnienia się Oświecenia wśród ludzi ${ }^{8}$.

Przeciętnym daleko do „odwagi myślenia”. Bliżej im raczej do następujących pięciu przykazań:

Po pierwsze, nie myśl. Po drugie, jak już musisz myśleć, to nie mów. Po trzecie, jak musisz mówić, to nie pisz. Po czwarte, jak musisz pisać, to się nie podpisuj. Po piąte, jak się podpisujesz, to się nie zdziw.

Drugim współczesnym przejawem bezmyślności jest redukcja myślenia do wymiaru pragmatycznego. Myślenie liczy się tylko w mierze, w jakiej przynosi realne skutki. Od początków nowożytnego rozwoju nauk przez teorię rozumiemy śmiałą hipotezę badawczą, dającą się doświadczalnie zweryfikować i mającą istotne pragmatyczne skutki. Dlatego badacze składający wnioski grantowe do Narodowego Centrum Nauki muszą zadeklarować, jakie patenty, nowe technologie lub przynajmniej rozwiązania problemów społecznych wynikną z ich badań. Tymczasem dla Platona theoros to dusza, która zanim znalazła się w ciele, żyła w świecie idealnym i za boskimi duszami zmierzała do miejsca prawdziwego i pięknego bytu, który był jej pokarmem. A kiedy nakarmiła się

\footnotetext{
${ }^{8}$ I. Kant, Was ist Aufklärung, w: T. Kroński, Kant, Warszawa 1966, s. 166.
} 
nim, wpadała w zachwyt, czyli theoria. Teoria to dla Platona zachwyt widokiem. W nastawieniu teoretycznym znajduje się zatem ten, kto słuchając muzyki Pergolesiego lub Mozarta, czytając wiersze Celana lub Herberta, kontemplując obrazy Rembrandta, wpada w zachwyt. W zachwyt może wpaść także matematyk nad fraktalem czy wzorem. Dlatego humaniści, składając granty do Narodowego Centrum Nauki, powinni raczej odpowiadać na pytania: w jaki rodzaj zachwytu zamierzają wpaść w trakcie badań? Jak zmieni on ich duszę? Kto jednak da im na to pieniądze, szczególnie, gdy nie będą w stanie wykazać pragmatycznych korzyści zachwytu? Myślenia nie można mierzyć jedynie skutkami. To bezmyślność. W myśleniu ważniejszy jest sam proces myślenia. Jan Twardowski: „Myślał myśliciel”.

Na bezmyślność ma wreszcie wpływ mierzalność. Według Kartezjusza, przedmiotem nauki może być tylko to, co da się zmierzyć. Dlatego wolność i zaufanie, które były zawsze podstawą życia Uniwersytetu, zastępuje biurokratyczna kontrola. Uniwersytet zaczyna przypominać Benthamowski Panopticon, wieżę nadzoru i kontroli, w której gros czasu i uwagi poświęca się nie na myślenie, lecz na planowanie i sprawozdawczość. Już nie tylko planujemy i sprawozdajemy, ale planujemy sprawozdania i sprawozdajemy plany. Gdy linie graniczne między planami i sprawozdaniami zleją się, zniknie szczelina wolnego myślenia. Czy biurokracja zwiększa efekty naszego myślenia? Wątpię. Kopernik, o zgrozo, nigdy nie był na Erazmusie. Jednak gdy dotarł na Uniwersytet w Padwie, bez problemu porozumiał się z tamtejszymi profesorami.

Immanuel Kant miał zerową „mobilność naukową”. Tylko raz wyjechał z Królewca do Gołdapi, by wygłosić kilka wykładów stacjonującym tam pruskim oficerom. Przez jedenaście lat był bezproduktywny, gdyż niczego nie opublikował. Co prawda po jedenastu latach opublikował Krytykę czystego rozumu, ale według aktualnych standardów oceny powinien był co cztery lata otrzymać ocenę negatywną.

3. Jaka powinna być rola uniwersytetów w czasach bezmyślności? Po pierwsze, powinny one uczyć odwagi samodzielnego krytycznego myślenia, zdolnego do namysłu nad własnymi przekonaniami i szacunku dla przekonań innych. Po wtóre, musimy uświadomić sobie, czym powinno być kształcenie. Nie możemy ograniczać się do kształcenia intelektu, pomijając kształcenie rozumu i rozsądku. Stajemy bowiem przed niewyobrażalnym rozwojem technologicznym, za którym nie nadąża mądrość. 
Obecnie przez kształcenie rozumiemy wyposażanie człowieka w wiedzę, umiejętności i kompetencje konieczne do sprawnego funkcjonowania na rynku pracy. Człowiek nie jest jednak tylko podmiotem na rynku pracy. Kształcenie przybrało obecnie technologiczną postać. Zostało zredukowane do nabywania wymiernych kompetencji, umiejętności i kwalifikacji. Trudno podważać znaczenia tych umiejętności, kompetencji i kwalifikacji koniecznych do życia we współczesnej cywilizacji technicznej. Celem kształcenia nie może być jedynie przygotowywanie podmiotów na rynek pracy. Dlatego Max Horkheimer w swoim słynnym wykładzie Odpowiedzialność i studia, wygłoszonym w 1952 roku po powrocie z USA, stwierdził, że kształcenie „powinno być poznaniem tego, co obchodzi nas jako ludzi, a nie tylko jako członków społeczeństwa przemysłowego".

Kształcenie musi polegać na wyposażeniu w wiedzę, ale także w moralne wartości, egzystencjalne sensy jako punkty oparcia, estetyczne przeżycia, które mają wystarczyć człowiekowi na całe życie. Musi dokonywać się poprzez przekaz kulturowy, gdyż to wielkie dzieła kultury europejskiej, wielkie wzorce moralne odsłaniają sens człowieczeństwa i sens życia. Dlatego Seneka napisał kiedyś do swego ucznia prokuratora Lucyliusza: „Wiesz, co jest potrzebne, by być dobrym prokuratorem, ponieważ kształciłeś się u mnie: littere" (literatura, sztuka, filozofia). Bez nich nie można być człowiekiem kulturalnym, a bez kultury nie można być dobrym prokuratorem.

Do kształcenia rozumu potrzebna jest kultura. Żyjemy zbyt krótko, by móc nabyć właściwego doświadczenia, a przez to mądrości - nabyć rozumu i rozsądku. Dlatego tak ważną rolę odgrywają dzieła kultury. Dzięki lekturze, jak pisał Wilhelm Dilthey, możemy przeżyć wiele różnych rodzajów egzystencji. Skrępowani i określeni przez realia życia zyskujemy wolność w czasie i przestrzeni ${ }^{10}$. Możemy odtwórczo przeżyć życie ludzi innych czasów i innych od naszego miejsc. Możemy podczas jednego własnego życia żyć wielokrotnie i dzięki temu nabyć rozmawiać z innym i go rozumieć. Pisał Paul Ricoeur:

Wbrew tradycji (...) trzeba stwierdzić, że rozumiemy siebie, jedynie odbywając dookolną drogę pośród znaków ludzkości utrwalonych w dziełach kultury. Cóż wiedzielibyśmy o miłości i o nienawiści, o uczuciach etycznych i ogólnie o tym

${ }^{9}$ M. Horkheimer, Odpowiedzialność i studia, „Kronos” 2 (2011), s. 240.

${ }^{10} \mathrm{~W}$. Dilthey, Budowa świata historycznego w naukach humanistycznych, tłum. E. Paczkowska-Łagowska, Warszawa 2004, s. 205. 
wszystkim, co nazywamy sobą, gdyby nie zostało to wypowiedziane i sformułowane przez literaturę?"11

Kształcenie jest zatem wewnętrzną formacją, kształtowaniem humanitaryzmu. Szczególnie na ten ostatni zwrócił uwagę Horkheimer, mając na myśli grozę wojny:

Po tej grozie, która się niedawno wydarzyła, i na przekór jej, nie mogę porzucić nadziei, że nie tylko w pierwszym okresie po katastrofie, ale i w nadchodzących dziesięcioleciach owa zapomniana już postawa stanie się znów celem kształcenia uniwersyteckiego. Ograniczenie studiów do nabywania umiejętności (...) nie wystarczy. Sędzia pozbawiony empatii oznacza śmierć sprawiedliwości ${ }^{12}$.

Wykształcenie jest zatem stanem ducha, który pozostaje nawet wówczas, gdy człowiek zapomni o wszystkich nabytych kompetencjach i sprawnościach, nawet wówczas gdy rozpadną się wszystkie formy życia społecznego. Zachowa godność i przyzwoitość w najbardziej ekstremalnych warunkach.

Jak jednak realizować takie zadanie kształcenia w sytuacji, kiedy uniwersytety, będące zawsze miejscem niezależnego myślenia i poszukiwania prawdy, stały się częścią światowej przedsiębiorczości? Na naszych oczach Uniwersytet przekształca się w korporację, w fabrykę wiedzy, gdzie wiedza staje się formą akumulacji kapitału, a profesorzy zarządzającymi bazami danych.

Uniwersytet-korporacja stał się podmiotem gry rynkowej, prawa popytu i podaży. Zważywszy na tyranię przeciętności, stawia nas to przed dramatycznym pytaniem: czy należy usunąć humanistykę i kulturę z Uniwersytetu tylko dlatego, że nie znajduje odpowiednio dojrzałych nabywców? Czy zatem Uniwersytet powinien służyć prawdzie, czy społeczeństwu? Czy alternatywa jest fałszywa? Na czym powinna zatem polegać ta służba? Czy na uleganiu najniższym gustom, demokracji bezpośredniej narzucającej swe przekonania i zasady na internetowych forach i ulicach, czy też na wychowywaniu społeczeństwa? Czy Uniwersytet ma pełnić funkcję autorytetu, czy ma godzić się na coraz dalej idące obniżanie wymogów kształcenia, by zrealizować ideał równości? Czy ma bronić wzorców, kanonów kultury języka, czy też poddać się społecznej presji.

${ }^{11}$ P. Ricoeur, Język, tekst, interpretacja, wybór i oprac. K. Rosner, tłum. P. Graff, K. Rosner, Warszawa 1989, s. 243.

${ }^{12}$ M. Horkheimer, Odpowiedzialność i studia, dz. cyt., s. 245. 
Odpowiedzi na tę alternatywę związane są z odpowiedzią na pytanie: kim jest człowiek i na czym polega jego dobro? Czy ma ono być określane przez społeczne i kulturowe mody, zapotrzebowania rynku pracy, ekonomiczne możliwości, politykę? Czy też jego określenie powinno wymagać namysłu nad europejską tradycją kultury i myśli? Rzecz w tym, że aktualnie Uniwersytet w coraz mniejszym stopniu stwarza warunki, by takie pytania stawiać i usiłować na nie odpowiadać.

„Uniwersytet-korporacja” przestał być też „Uniwersytetem-świątynią”, miejscem zatrzymania, refleksji. Stał się „Uniwersytetem-pasażem”, miejscem pospiesznego przejścia z domu do pracy i z pracy do domu, z pracy bądź domu na inną uczelnię lub inny kierunek studiów, na kurs i z kursów, na wolontariat i z wolontariatu. „Uniwersytet-pasaż” przestaje być miejscem kształcenia, a staje się miejscem zaliczania punktów koniecznych do uzyskania dyplomu i budowy CV pod kątem rynku pracy. Wypełnia się ów pasaż jedynie podczas okresu rekrutacji i sesji egzaminacyjnej. „Uniwersytet-pasaż pływa w „płynnej nowoczesności”. Wszystko jest w nim chwilowe, zmienne i płytkie: ustawy, rozporządzenia, systemy ocen, autorytety, a nawet notatki studenckie krążące w Internecie.

Jaka czeka nas przyszłość? Uniwersytet powinien na nowo stać się przestrzenią wolnej myśli, niezależnej od nacisków polityki i gospodarki. Powinien wyzwolić się spod biurokratycznego jarzma i odzyskać zaufanie, by mógł oddać się pełnemu, uniwersalnemu kształceniu. Jakość życia społecznego, a przede wszystkim to, czy będziemy się chlubić człowieczeństwem, czy go wstydzić, będzie w dużej mierze zależna od kształcenia.

Nie tylko intelekt się liczy, ale przede wszystkim rozum. Powróćmy na koniec do metafory Bollnowa. Intelekt uczy nas, jak zbudować dom. Jeśli ten dom będzie nawet nowoczesny, energooszczędny, przyszłościowy, na nic się nie zda, jeśli nie będziemy umieli go rozumnie współzamieszkiwać. 
Tadeusz Gadacz, prof. zwyczajny na Wydziale Humanistycznym AGH w Krakowie. Uczeń i wieloletni współpracownik ks. profesora Józefa Tischnera. Doktorat uzyskał $w 1984$ roku, habilitację $w$ 1990, a profesorem tytularnym został w 2009. W latach 1991-1995 był dziekanem Wydziału Filozofii Papieskiej Akademii Teologicznej w Krakowie, 1996-1999 kierownikiem Katedry Filozofii Religii na Wydziale Filozoficznym Uniwersytetu Warszawskiego, 2002-2008 profesorem $w$ Instytucie Filozofii i Socjologii Polskiej Akademii Nauk, 20092017 dyrektorem Instytutu Filozofii i Socjologii Uniwersytetu Pedagogicznego w Krakowie. Wykłada także w Collegium Civitas od jego powstania (1998). W latach 1999-2002 był koordynatorem $w$ dziedzinie nauk humanistycznych i zastępcą redaktora naczelnego Redakcji Encyklopedii PWN. W latach 20032007 był przewodniczącym Komitetu Nauk Filozoficznych PAN. Obecnie jest przewodniczącym Polskiego Towarzystwa Etycznego oraz Zarządu Hospicjum Dziecięcego im. Ks. prof. Józefa Tischnera. Zajmuje się historią filozofii XX wieku, filozofią człowieka, filozofią religii, kondycją myślenia, analizą przemian kultury i cywilizacji, mentoringiem. Jest autorem ponad 200 publikacji naukowych polskich i zagranicznych. Ostatnio wydał Rozumowe poznanie Boga, Filozofia człowieka jako filozofia losu, O umiejętności życia, Bóg w filozofii XX wieku, O ulotności życia, Historia filozofii XX wieku. Nurty, t. 1: Filozofia życia, Filozofia ducha, Pragmatyzm, t. 2: Neokantyzm, Filozofia dialogu, Filozofia egzystencji. 
Aniwersytet Papieski

Tf: Ja! Jana Pawła II

(ii w Krakowie 